\title{
Cottbus 2000
}

\author{
By Ron Holloway
}

Fall 2001 Issue of KINEMA

\section{0th COTTBUS FESTIVAL OF EAST EUROPEAN CINEMA}

For its first nine years, Cottbus was a film festival with an eye on young (or new) directors based in what used to be the socialist bloc of East Europe. For its 10th anniversary (1-5 November 2000), however, festival director Roland Rust modified its image slightly to embrace all films of quality found in those restructured film lands. Now Cottbus ranks as a splendid showcase of films in all categories of production found in scattered studios from Berlin eastward to Siberia, one that informs (in a 200-page German-English catalogue) as well as programs. Moreover, film professionals familiar with the field are welcome to participate in one of the nine juries, three of which offer purses from the City of Cottbus, Land Brandenburg, and individual sponsors.

Besides the three main official competitions -- features, shorts, children and youth films -- the 10th Cottbus festival also programmed a diverse series of films under catch-all titles: Specials, Spectrum, National Hits, and a Regional Focus on Central Asian Cinema (Kyrgyzstan, Turkmenistan, Uzbekistan) of the 1990s. If that wasn't enough, then you could participate in the "Connecting Cottbus" forum, a platform for promoting cooperation and coproduction between potential partners from East and West Europe.

One did not have to look far to find evidence that East-West European coproductions are becoming more plentiful. Two of the top awarded films -- Dito Tsintsadze's Lost Killers (Germany) and Achim von Borries's England! (Germany) -- were not only produced in the West, but they were also directed by filmmakers with an awareness and sensitivity for issues in the East. Add to these Nana Jorjadze's 27 Missing Kisses (Germany-Georgia-Denmark-France-UK) and Jan Hřebejk's Musíme si pomáhat (Divided We Fall, Czech Republic), and you have a quartet of four important feature films in the competition that have something in common: all are tragicomedies of outstanding quality.

In Lost Killers, awarded the main prize, Georgian director Dito Tsintsadze follows a pair of fumbling hitmen, the Croatian Branko and the Georgian Merab, around the city of Mannheim as they stalk their prey like the Marx Brothers on the loose. Neither know exactly why they are to rub out an unsuspecting businessman, much less how to find him in the first place -- not even when he's standing right next to Merab in a lavatory! Each time a ripe opportunity presents itself, something absurd and coincidental stymies the pair -- like the sudden appearance of a giant illegal Haitian fugitive, who's willing to sacrifice one of his kidneys to help his friend, a pint-sized Vietnamese prostitute, to get her teeth fixed! And so this weird story of lost people in a big city meanders along, sometimes sad, sometimes funny.

England!, primarily a humane statement on the Chernobyl tragedy, also weaves its magic as a tragicomedy. Its personable hero, the Ukrainian Valery, has only one wish: to leave the contaminated, quarantined area around Chernobyl and head for the shores of England. So he breaks out of the guarded enclave with a friend and heads west -- only to be stranded in Berlin and hampered by a constant nosebleed that foreshadows the end. Using his wit and charm, Valery wins the support of a new-found friend, celebrates Christmas, accepts his fate, and finds a way to eventually realize his dream. A sensitive debut feature by a director to watch, England! above all features a remarkably adept cross-cultural cast. At Cottbus it was awarded by three juries, receiving the Promotion Prize by the International Jury, the Ecumenical Prize, the Don Quixote Prize by the International Federation of Film Clubs, and the Audience Prize.

Georgian director Nana Jorjadze's 27 Missing Kisses appears on the surface to be little more than a film about a girl's coming-of-age, about sex and fantasies, about the absurdities of provincial life in a "sleepy Eastern town" in the Caucasus. But below the surface runs a stream of delightful humour that collides headlong with the aguish and pain of two adolescents in the throes of growing up. When 14-year-old Sybille arrives on the scene to spend the summer vacation with her aunt, she falls in love with a middle-aged widower, whose teenaged son Mickey in turn has a crush on Sybille. During this summer of the magical eclipse (stunningly photographed by Phedron Papamichael) Sybille promises Mickey 100 kisses -- he has only received 73 when his world is suddenly turned upside down. 27 Missing Kisses, packed with twists 
and surprises, has some heightened magical moments (that image of a big ship carted across land) and a sequence of sheer hilarity, when a pirated copy of Emmanuelle is screened at the local munitions factory!

Lastly, Hřebejk's tragicomedy Divided We Fall leans on the Holocaust theme to sketch some incredible yet plausible events in a small Bohemian town in 1943 during the last critical year of the German occupation. Scripted by Petr Jarchovský, the same talented screenwriter who penned the Czech box-office hit Cosy Dens (1999), Divided We Fall shifts neatly from light bucolic scenes to painfully tragic conflict as an average family couple wrestle with the reality of hiding a Jewish neighbour under the eyes of town officials. No one is spared a poke in the ribs in Divided We Fall -- neither Czech collaborators, nor Nazi officers, nor Russian liberators, nor jealous neighbours, nor the Jew in hiding -- all are heroes and cowards against the backdrop of small town provincialism. Considering the foibles of life that mould human character, who would have it any different? The film was awarded the FIPRESCI (International Critics) Prize.

Czech entries as a whole were valued at Cottbus. In the feature film competition Alice Nellis's Ene Bene (Eeeny Meeny), a comedy about a woman's tactics to deal with a lazy husband faking an illness, was awarded a share of the Promotion Prize. In the children and youth film competition Iva Švarcová's Als Grossvater Rita Hayworth liebte (When Grandpa Loved Rita Hayworth), a coproduction with Germany and Switzerland, was awarded the top prize, while Milan Cieslar's Pramen života -- Der Lebensborn (The Spring of Life) and Václav Vorlíček's Sokoliar Tomáš (Tomas and the Falcon King), a coproduction with Slovakia, Poland, France, and Hungary, received special mentions.

\section{References}

\section{AWARDS}

\section{Competition}

Best Feature: Lost Killers (Germany), Dito Tsintsadze

Promotion Prizes: England! (Germany), Achim von Borries, and Ene Bene (Eeny Meeny, Czech Republic), Alice Nellis

Best Short: Námořnický valik (The Sailor's Waltz, Czech Republic), Ramunas Greicius

2nd Prize: Beket (Bus Stop, Kirgizstan), Aktan Abdykalykov, Ernest Abdyshaparov

Special Mention: Otevřená krajina svobodného muže (The Open Countryside of a Lonely Man, Czech Rep.), Pavel Göbl

Best Children and Youth Film: Als Grossvater Rita Hayworth liebte (When Grandpa Loved Rita Hayworth, Germany-Switzerland-Czech Republic), Iva Švarcová

Special Mentions: Pramen života - Der Lebensborn (The Spring of Life, Czech Republic), Milan Cieslar, and Sokoliar Tomáš (Tomas and the Falcon King, Slovakia-Poland-France-Hungary-Czech Republic), Václav Vorlíček

Other festival awards

FIPRESCI Prize (International Critics): Musime si pomáhat (Divided We Fall, Czech Republic), Jan Hřebejk

Ecumenical Prize: England! (Germany), Achim von Borries

Don Quixote Prize (International Federation of Film Clubs): England! (Germany), Achim von Borries

Audience Prize: England! (Germany), Achim von Borries

Findling Prize (Film Art Houses): Mehanizam (Mechanism, Yugoslavia), Djordje Milosavljevi

Debut Film Prize: Blagajnica hoce ici na more (The Cashier Wants to Go to the Seaside, Croatia), Dalibor Matani 


\section{Author Information}

Ron HOLLOWAY (1933-2009) was an American critic, film historian, filmmaker and correspondent who adopted Europe as his home in the early fifties and spent much of his life in Berlin. He was an expert on the study of German cinema and against all odds produced, with his wife Dorothea, the journal German Film, keeping us up-to-date with the work of directors, producers and writers and the showing of German films around the world.

In 2007, Ron Holloway and his wife were awarded the Berlinale Camera Award. Ron also received the Bundesverdienstkreuz (German Cross of Merit), Polish Rings, Cannes Gold Medaille, the American Cinema Foundation Award, the Diploma for Support of Russian Cinema and an honorary award from the German Film Critics' Association.

Ron was also a valued contributor to Kinema for the past fifteen years. 